\title{
Cave Art and the Origins of Language
}

\author{
Dein Simon* \\ Department of Archaeology, UK \\ Submission: July 12, 2018; Published: July 23, 2018 \\ *Corresponding author: Dein Simon, Department of Archaeology, UK, Email: s.dein@ucl.ac.uk
}

Keywords: Cave Art; Origins; Language; Upper Paleolithic; Language; Archaeological; Linguists; Ice Age; Gibraltar; Anthropological; Paintings; Beasts; Societies; Rock shelters; Population; Drawing

\section{Opinion}

The term Cave paintings, also known as parietal art, refers to painted drawings on cave walls or ceilings, mainly of prehistoric origin, originating roughly 40,000 years ago (around 38,000 $\mathrm{BCE}$ ) in Eurasia. The term is generally deployed in connection with Stone Age art created during the last Ice Age, between about 40,000 and 10,000 BCE - a period generally referred to as the 'Upper Paleolithic'. Cave art has been found on every continent except Antarctica. In Europe, about 350 sites have been discovered, from the southernmost tip of the Iberian Peninsula (Gibraltar) to the Russian Urals. Nearly half (about 160) of these paintings are located in France. There are a few 'hot-spots', all of which are to be found within the region of Franco-Cantabrian Cave Art (40,000-10,000 BCE), in northern Spain and southern France - either in shallow rock shelters, or in deep caves.

Much of the archaeological and anthropological work in this area have focused upon the motivations for drawing them. However, the focus in this brief overview is what cave paintings teach us about the origins of human language.

\section{Interpretations of Cave Art}

Henri Breuil [1] interpreted the paintings as hunting magic to increase the abundance of prey- a form of 'Sympathetic magic' which was made to bring good fortune to hunters. Another theory, developed by David Lewis-Williams [2] builds upon ethnographic studies of contemporary hunter-gatherer societies, arguing that the paintings were made by paleolithic shamans who would retreat into the darkness of the caves then subsequently enter a trance state. In this altered state of consciousness, he/she would then paint images reflecting his or her visions. R. Dale Guthrie [3] identifies a wide range of skill and age among the artists and hypothesizes that the main themes in the paintings and other artifacts (powerful beasts, risky hunting scenes and the representation of women in the Venus figurines) suggest that the paintings are the work of adolescent males (hypersexual, strong), who constituted a large part of the human population at the time.

Finally, prehistorians speculate that cave art is linked to ceremonial activities. According to this theory, the fact that many of the best-decorated caves were uninhabited, that a significant number of decorated chambers were in the least accessible areas of the cave complex, and that deep caves were visited only by a very small number of people, suggests that cave art was not created for public uptake. Rather, it was part of a ceremonial or quasi-religious activity. Most of the animals depicted were infrequently hunted because they were powerful and dangerous species. The images focus on parts deemed most importantantlers for reindeer and belly for horses.' Of note, artifacts from both periods also displayed a scarcity of human figures. When they appeared, however, human figures in devotional settings of both eras were characteristically unsexed or masculine, with female figures appearing almost exclusively in domestic settings.

\section{Language origins}

There is emerging evidence that our ancestors emerged as a species 200,000 years ago and language developed about 100,000 years later. Most biologists, linguists, and anthropologists believe language occurred well before cave art. The gene believed to be responsible for language acquisition, the FOXP2 gene, has been found in Neanderthals

Some specific features of cave art may provide clues about how our symbolic, multifaceted language capabilities evolved. Shigeru Miyagawa, Cora Lesure \& Vitor A Nóbrega [4] argue that many of the caves in which art has been found are important acoustic 'hot spots.' In these caves, sounds echo louder and more intensely the deeper one goes inside. Many of the drawings are to be found in these sections of the cave and, for the many different scientists, would seem to indicate that the sounds are the primary reasons the drawings are there; even some areas 
that would've been better for drawing on the walls were ignored in favour of these spots. The drawings would then depict sounds that humans made while in the caves.

The authors refer to this convergence of sound and drawing as 'cross-modality information transfer,' a convergence of auditory information and visual art that, the authors write, "allowed early humans to enhance their ability to convey symbolic thinking."

\section{Symbols}

Previously overlooked patterns in the cave art of southern France and Spain suggest that man might have learned written communication 25,000 years earlier than was previously thought. Symbols are frequently found in cave art which are separate from the representation of animals such as horses and bison. Ice Age caves contain more than twice as many abstract signs as animal images. According to recent research by Genevieve von Petzinger [5], this mysterious type of cave art may be the earliest known pictorial language. Some are gathered in groups, many appear in ones or twos, while others are mixed in with the caves' images of animals. The abstract signs include triangles, squares, full circles, semicircles, open angles, crosses and groups of dots. Others demonstrate more complexity: drawings of hands with distorted fingers (known as negative hands); rows of parallel lines (called finger flutings); diagrams of branch-like symbols known as penniforms, or little sketches of hut-like entities called tectiforms. In total, 26 specific signs are deployed repeatedly in these caves, created in the millennia when Europe descended into - and emerged from - the last great Ice Age. Von Petzinger argues that the symbols indicate that our ancestors moved from realistic representations of ideas - like beautiful images of bison and mammoths - to symbolic representation and are a code painted on to rock by Cro-Magnon people, who inhabited Europe 30,000 years ago.

\section{Neanderthal's as Artists}

Both fossil and DNA evidence of speech adaptations in Neanderthals or earlier hominins, and archeological indications of symbolic behavior in Neanderthals, support the presence of some form of Neanderthal language. Until now, the oldest discovered cave art was roughly 40,000 years old, consisting of stenciled hands and animals in an Indonesian site that was dated in 2014, and discs and hand stencils in a cave in Cantabria, Spain, that were discovered by Pike and his colleagues in 2012. While Humans are considered to have arrived in Europe from Africa around 40,000-45,000 years ago, three caves in different parts of Spain contain artworks that are at least 65,000 years old. Evidence suggests that Neanderthals painted caves in what is now Spain before their cousins, Homo sapiens, even arrived in Europe.

The finding suggests that the extinct hominids, once assumed to be intellectually inferior to humans, may have been artists with complex beliefs [6]. These dates provide evidence of indisputable Neanderthal creativity, long before Homo sapiens arrived in Europe and accord with evidence of sophisticated tools, burials, and organized use of space has slowly accumulated at a plethora of sites across Europe and the Middle East. New discoveries continue to challenge our conception of Iberian Neanderthals. It is likely that they used complex thinking processes- Neanderthals had the ability to think, leading researchers to speculate about Neanderthal language. The above studies may provide some evidence concerning the evolution of language. Future research should concentrate on understanding the symbolism associated with cave paintings and how this reflects early Man's cognitive abilities.

\section{References}

1. Breuil H (1952) Four Hundred Centuries of Cave Art. Hacker Art Books, UK.

2. Lewis Williams D (2003) The Mind in the Cave: Consciousness and the Origins of Art London. Thames, Hudson (Eds.), London, UK.

3. Guthrie D (2005) The Nature of Paleolithic Art. The University of Chicago Press, USA.

4. Miyagawa S, Lesure C, Nóbrega VA (2018) Cross-Modality Information Transfer: A Hypothesis about the Relationship among Prehistoric Cave Paintings, Symbolic Thinking, and the Emergence of Language. Frontiers in Psychology 20(9): 115.

5. Genevieve von Petzinger (2017) The First Signs: Unlocking the Mysteries of the World's Oldest Symbols. Atria

6. Hoffmann DL, Standish CD, García-Diez M, Pettitt PB, Milton JA, et al. (2018) U-Th Dating of carbonate crusts reveals Neandertal origin of Iberian cave art. 23: 912-915.

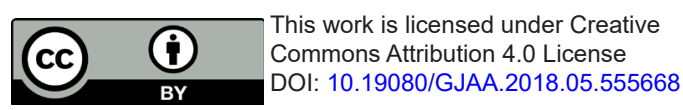

\begin{tabular}{l} 
Your next submission with Juniper Publishers \\
will reach you the below assets \\
- Quality Editorial service \\
- Swift Peer Review \\
- Reprints availability \\
- E-prints Service \\
- Manuscript Podcast for convenient understanding \\
- Global attainment for your research \\
- Manuscript accessibility in different formats \\
( Pdf, E-pub, Full Text, Audio) \\
- Unceasing customer service \\
Track the below URL for one-step submission \\
https://juniperpublishers.com/online-submission.php \\
\hline
\end{tabular}

